Vol. 1, Issue 1. May 2017

OPINION PIECE

\title{
A Framework to Explore Roles Within Student-Staff Partnerships in Higher Education: Which Students Are Partners, When, and in What Ways?
}

Catherine Bovill, Institute for Academic Development, University of Edinburgh, Edinburgh, UK Contact: catherine.bovill@ed.ac.uk

\section{INTRODUCTION}

We are witnessing an expansion of research and practice involving students-as-partners in higher education. Within the "Students as Partners" (SaP) discourse there is growing recognition that SaP initiatives are diverse (Dunne, 2016). Authors such as Bovill, Cook-Sather, Felten, Millard, and Moore-Cherry (2016), Bryson, Furlonger, and Rinaldo-Langridge (2015), Buckley (2014), and Healey, Flint, and Harrington (2014) have suggested that SaP research and practice can be differentiated in a range of ways. For example, there are SaP initiatives focused on either governance or pedagogy; SaP can involve work with individuals, small groups of students or whole cohorts of students; and in situations where a subset of students are invited to become partners, they may be elected or selected. Many of the discussions about which students are involved in SaP work emphasises the importance of inclusion as a principle underpinning practice (Moore-Cherry, Healey, Nicholson, \& Andrews, 2016; Bovill et al., 2016), and some practitioners and researchers have underlined the importance of trying to enhance inclusion of hard-to-reach students (REACT, n.d.) and previously excluded groups (Cook-Sather \& Agu, 2013).

Whilst recent work is drawing attention to the potential benefits of whole cohort approaches to SaP (Bovill, 2017; Moore-Cherry et al., 2016), it may be difficult, impossible, or even undesirable in some contexts to involve all students all of the time. This might seem heresy within a new journal focused on SaP, but there is a danger that partnership is perceived to be universally positive, to involve all students and that all situations call for partnership. I support wholeheartedly the values that underpin SaP work: respect, responsibility, and reciprocity (Cook-Sather, Bovill, \& Felten, 2014), and therefore I try to enact these partnership values in all of my work, but I also recognise pragmatically that there are situations where partnership may either be challenging or undesirable.

A range of challenges to enacting partnership have been highlighted in the literature. These challenges include: the relative difficulty of establishing and maintaining partnerships when working within tight time constraints; situations where teachers have limited contact 
with students; situations where the requirements of professional bodies might constrain what is possible; the large size of many university classes; the resistance of students if they have been enculturated into a passive learning mode at university through over-reliance on lectures; student skepticism about partnership if they have experience of previous empty claims of partnership; and staff skepticism about the benefits of involving students more fully in learning and teaching (Bovill, Morss, \& Bulley, 2009; Bovill \& Bulley, 2011; Cook-Sather et al., 2014). Whilst Bovill et al. (2016) and Cook-Sather et al. (2014) suggest a range of ways in which these challenges can be overcome and re-envisaged, the clear message is that full partnership might not always be possible or desirable.

Using the ladder of student participation in curriculum design, I have argued elsewhere (Bovill \& Bulley, 2011) that there are many levels of participation that are possible, and that partnership implies and requires a very high level of participation. This conceptualisation of partnership as just one of many types of student participation helps to highlight the challenge of trying to work in partnership in all contexts-meaningful partnership requires a high level of equality and contribution from partners.

There are benefits to recognising the limitations of partnership. In many situations where partnership is promoted, student views are reified at the risk of overlooking the important contribution of expert teachers. Similarly, if we try to mainstream partnership approaches that have been successful in several small classes, we should not be surprised if the partnership that results takes on very new forms in large-scale settings. We run the risk of enacting partnerships that do not feel like partnerships to those involved, with the resultant danger of alienating some students and academic staff in the longer term.

I suggest that the principles of respect and responsibility should, and can, inform most of the relationships between students and teachers in higher education, but reciprocity is a more complex issue due to academic staff taking final responsibility for some high-stakes issues such as assessment. Although some authors have provided excellent examples that suggest partnership is possible in assessment (see, for example, Deeley, 2014), we need to recognise that there are times when specific students, groups of students, or teachers need to take specific responsibility for learning and teaching processes. Acknowledging that contexts are different helps us to adopt appropriate SaP approaches in particular settings. This is about recognising the huge range of ways in which different students can engage as partners in different aspects of learning and teaching at different times.

One framework that helps in considering which students and staff should be partners, when and in what ways, is the participation matrix. This is a tool that has been used extensively in the international development field to map the different types of engagement by different actors at different stages of projects (Department for International Development, 2003). The matrix is frequently used to map out stakeholders and partners participating in development projects, and has recently been used to explore the roles of students and other stakeholders involved in participatory educational building design (Könings, Bovill \& Woolner, in press). Figure 1 illustrates a participation matrix as an example of collaborative evaluation in a classroom. 
Figure 1. Example participation matrix illustrating the nature of participation by students and staff in a collaborative evaluation project

\begin{tabular}{|c|c|c|c|c|c|}
\hline $\begin{array}{l}\text { Level of } \\
\text { involvement } \\
\text { Action } \\
\text { research stage }\end{array}$ & Inform & Consult & Participate & Partnership & Control \\
\hline 1. Course design & $\begin{array}{l}\text { All } \\
\text { students }\end{array}$ & & & & Teacher \\
\hline $\begin{array}{l}\text { 2. Evaluation } \\
\text { design }\end{array}$ & & $\begin{array}{l}\text { Student } \\
\text { group } \\
(n=18)\end{array}$ & & $\begin{array}{l}\text { Teacher }+ \\
\text { Student } \\
\text { group }(n=2)\end{array}$ & \\
\hline $\begin{array}{l}\text { 3. Conduct } \\
\text { evaluation }\end{array}$ & & Teacher & $\begin{array}{l}\text { Student } \\
\text { group } \\
(n=18)\end{array}$ & & $\begin{array}{l}\text { Students } \\
(n=2)\end{array}$ \\
\hline $\begin{array}{l}\text { 5. Analysis of } \\
\text { results }\end{array}$ & $\begin{array}{l}\text { Student } \\
\text { group } \\
(n=12)\end{array}$ & & & $\begin{array}{l}\text { Teacher }+ \\
\text { student } \\
\text { group }(n=8)\end{array}$ & \\
\hline 6. Dissemination & & & & $\begin{array}{l}\text { Teacher }+ \\
\text { student } \\
\text { group }(n=8)\end{array}$ & \\
\hline
\end{tabular}

All SaP projects will look different and involve different actors. The participation matrix offers a way to be transparent about the different roles of different actors at different stages of a SaP project. In common with many SaP projects, this example shows the teacher leading the initiative at the start (Bovill, 2014; Heron, 1992). At later stages the teacher is working in partnership with different subsets of the student cohort.

One of the drawbacks of the matrix is that it does not reveal underpinning rationales or values. As a teacher, my values are critical in guiding the way that I relate to students and colleagues. I try to ensure at all times that I provide meaningful participation opportunities to all students, that participation opportunities are voluntary, that I enable students to adapt their roles at different stages of work as appropriate, that I create an environment of respect in which students and I can learn and develop, and that I remain open-minded to suggestions from students for new directions in our work. 


\section{IMPLICATIONS FOR PRACTICE}

The participation matrix is based on the premise that it might not be desirable to aim for full partnership all the time and that students or staff may be in control at different stages of work. Importantly, this matrix can also be used by students to explore which teachers should be involved in projects they are leading, at what stages, and in what ways. Ideally, teachers and students come together to plan and undertake work, but where one person starts a project and then encourages other colleagues to join, the matrix can be helpful in highlighting who of those involved need to lead, work in partnership, participate, be consulted, or simply be informed about specific elements of work and when. The matrix helps us acknowledge that some kinds of student participation may not be desirable in all situations; for example, a new class of inexperienced students might feel out of their depth if a teacher tries to hand over control of designing the whole curriculum on day one without guidance (Bovill \& Bulley, 2011; Shor, 1992). In other situations, staff participation may not be desirable, such as when students are happy and capable to lead work uninterrupted by staff, or when staff are struggling to relinquish control. The participation matrix enables us to consider carefully how and when different actors play different roles in collaboration, and therefore has immense potential to be useful to the higher education SaP community.

\section{NOTES ON CONTRIBUTOR}

Catherine Bovill is a Senior Lecturer in Student Engagement, Institute for Academic Development, University of Edinburgh. She is a Senior Fellow of the UK Higher Education Academy, and an Editorial Board member for Teaching in Higher Education. She has published and presented widely on students-aspartners and co-creation of curricula.

\section{REFERENCES}

Bovill, C. (2017). Whole cohort co-creation of learning and teaching in higher education: Enhancing the relationship between teacher and students. Manuscript in preparation.

Bovill, C. (2014). An investigation of co-created curricula within higher education in the UK, Ireland and the USA. Innovations in Education and Teaching International, 51(1), 15-25.

Bovill, C., \& Bulley, C. J. (2011). A model of active student participation in curriculum design: Exploring desirability and possibility. In Rust, C. Improving Student Learning (18) Global theories and local practices: institutional, disciplinary and cultural variations. Oxford: The Oxford Centre for Staff and Educational Development (pp. 176-188). Proceedings of the 2010 18th International Symposium/ISSOTL Conference, 19-22 October, Liverpool.

Bovill, C., Cook-Sather, A., Felten, P., Millard, L., \& Moore-Cherry, N. (2016). Addressing potential challenges in co-creating learning and teaching: Overcoming resistance, navigating institutional norms and ensuring inclusivity in student-staff partnerships. Higher Education, 71(2), 195-208. 
Bovill, C., Morss, K., \& Bulley, C. (2009). Should students participate in curriculum design? Discussion arising from a first year curriculum design project and a literature review. Pedagogical Research in Maximising Education, 3(2), 17-26.

Bryson, C., Furlonger, R., \& Rinaldo-Langridge, F. (2015, July). A critical consideration of, and research agenda for, the approach of "students as partners." Paper presented at the International Conference on Improving University Teaching, Ljubljana, Slovenia.

Buckley, A. (2014). How radical is student engagement? (And what is it for?). Student Engagement and Experience Journal, 3(2). Retrieved from http://dx.doi.org/10.7190/seej.v3i2.95

Cook-Sather, A., \& Agu, P. (2013). Students of color and faculty members working together toward culturally sustaining pedagogy. In J. E. Groccia \& L. Cruz (Eds.), To improve the academy: Resources for faculty, instructional, and organizational development (Vol. 32, pp. 271-285). San Francisco: Jossey-Bass.

Cook-Sather, A., Bovill, C., \& Felten, P. (2014). Engaging students as partners in learning and teaching: A guide for faculty. San Francisco: Jossey-Bass.

Deeley, S. (2014). Summative co-assessment: a deep learning approach to enhancing employability skills and attributes. Active Learning in Higher Education 15(1), 39-51.

Department for International Development. (2003). Tools for Development: A Handbook for those Engaged in Development Activity. Retrieved from http://www.Imgforhealth.org/node/103.

Dunne, E. (2016). Design thinking: A framework for student engagement? A Personal view. Preface. Journal of Educational Innovation, Partnership and Change, 2(1). Retrieved from https://journals.gre.ac.uk/index.php/studentchangeagents/article/view/317

Healey, M., Flint, A., \& Harrington, K. (2014). Students as partners in learning and teaching in higher education. York: Higher Education Academy. Retrieved from https://www.heacademy.ac.uk/engagement-through-partnership-students-partnerslearning-and-teaching-higher-education

Heron, J. (1992). The politics of facilitation: Balancing facilitator authority and learner autonomy. In J. Mulligan \& C. Griffin (Eds.), Empowerment through experiential learning: Explorations of good practice (pp. 66-75). London: Kogan Page.

Könings, K.D., Bovill, C., \& Woolner, P. (in press). Towards an Interdisciplinary Model of Practice for Participatory Building Design. European Journal of Education

Moore-Cherry, N., Healey, R., Nicholson, D.T., \& Andrews, W. (2016) Inclusive partnership: Enhancing student engagement in geography. Journal of Geography in Higher Education, 40(1) 84-103.

REACT (n.d.). Realising Engagement Through Active Culture Transformation. Retrieved from http://www.studentengagement.ac.uk/index.php

Shor, I. (1992). Empowering education: Critical teaching for social change. London: University of Chicago Press 